\title{
Zwierzęta w chińskim: wartościowania i tabu
}

\section{Animals in Chinese: values and taboo}

\author{
Ida Stria \\ INSTYTUT JĘZYKOZNAWSTWA, UNIWERSYTET IM. ADAMA MICKIEWICZA \\ AL. NIEPODLEGŁOŚCI 4, 61-874 POZNAŃ \\ idakozm@o2.pl
}

\begin{abstract}
This work is the result of an ethnolinguistic research in the animal lexical area. The analysis is based on the notion of the linguistic picture of the world (LPW). One of the underlying elements of LPW is division of the world into taboo (the sacred) and noa (the profane). This division is reflected in various idiomatical expressions, which serve as the basis of this work. The aim of this study was to outline the system of values connected to animal symbolism. The author has analysed Chinese word combinations containing 6 zodiac animals. These animals seem to be an important part of Chinese culture with a high symbolic load. The Zodiac in the beliefs of the Chinese carries a positive meaning. However, the analysis of the idioms containing the names of the zodiac animals provides completely different conclusions. On the basis of the lexical material, it can be concluded that various types of symbolism are attributed to the zodiac animals in the Chinese language, not always resulting from their place in mythology.
\end{abstract}

\section{Wstęp}

Człowiek jest osadzony w konkretnej kulturze a poprzez socjalizację kreuje swoją tożsamość i mentalność, które sprawiają, że patrzy na świat w zgodzie $\mathrm{z}$ regułami $\mathrm{i}$ zachowaniami obowiązującymi $\mathrm{w}$ danym społeczeństwie. Poprzez wychowanie uczony on jest skali wartości, która pozostaje zakodowana $\mathrm{w}$ podświadomości. Te reguły życia odzwierciedlone są w języku w postaci utartych połączeń wyrazowych, które szeroko można nazwać frazeologizmami. 
Niniejsza praca ma na celu analizę frazeologizmów chińskich, które zawierają nazwy zwierząt i próba zarysowania systemu wartości powiązanego z symboliką zwierzęcą. Dalszym celem badań będzie także ocena wpływu chińskiego systemu wierzeń na te zjawiska językowe. W artykule zaprezentowanych jest sześć zwierząt, co stanowi połowę chińskiego zodiaku.

Podstawę teoretyczną analizy stanowi pojęcie językowego obrazu świata (JOS), który wg Bartmińskiego (2006: 12) jest „[...] zawartą w języku, różnie zwerbalizowaną interpretacją rzeczywistości dającą się ująć w postaci zespołu sądów o świecie”. JOS odzwierciedla, w jaki sposób członkowie danej grupy społecznej kategoryzują świat. Są to kategorie oparte na wartościowaniach, których skrajnymi przykładami są tabu i noa.

W wielu kulturach na świecie imię lub nazwa traktowane były jako nieodłączna cecha danego przedmiotu, osoby czy zjawiska; rzecz nazwana identyfikowana była wręcz z jej nazwą. Imię reifikowano i dlatego też istniało (lub nadal istnieje) przekonanie, że to, co wypowiedziane, może się spełnić. Sam wyraz tabu jest pierwotnie umotywowany religijnie. Pochodzi on $\mathrm{z}$ tongijskiego tapu (przez angielskie taboo) w znaczeniu 'zakazany, święty'. Encyklopedia PWN definiuje tabu następująco:

tabu [polinezyjskie tapu 'zakazane', 'nietykalne', 'święte', 'przeklęte'], zakaz kontaktowania się $\mathrm{z}$ określonymi osobami, zwierzętami lub przedmiotami oraz przebywania w określonych miejscach [...].

Freud (1993: 23) twierdzi, że wyraz tabu jest w swoim znaczeniu zbliżony do gr. agos (áyos) czy łac. sacer ('święty', 'przeklęty'). Wyjaśnia, że podobne znaczenie miałby święty lęk.

W opozycji do tabu (sacrum) stoi noa (profanum), rzeczy zwyczajne, powszechne, świeckie. Wyrazy, które wywołują silne uczucia (wstyd, strach), zastępuje się wyrazami „bezpiecznymi”. Zwykle wyrazy tabu należą do domeny rzeczy niebezpiecznych (ogień, wilki) lub świętych (bogowie). Inne przykłady to słownictwo związane $\mathrm{z}$ metabolizmem (wymioty, wydaliny) lub ze współżyciem seksualnym (stosunek, ciąża) czy śmiercią (Andersson 1985: 79).

Zwyczaj omijania wyrazów tabu jest szczególnie widoczny w krajach chińskojęzycznych, jako że język chiński obfituje w homonimy. Niestosowne jest obdarowywanie innych np. zegarami, ponieważ wyrażenie 'podarować zegar' (送钟, sòng zhōng) brzmi identycznie jak 'czuwać nad zmarłym' (送终). Tabu obejmuje nie tylko wyrazy będące w relacji całkowitej homofonii (钟, zhōng / 终, zhōng) ale także te, gdzie wymowa sylaby różni tylko i wyłącznie tonem, np. 'śmierć' (死, š̌) oraz 'cztery' (四, sì).

Często zakazane jest lub niewskazane wymieniać czyjeś imię. W tradycji chrześcijańskiej imię boskie nie powinno być używane bez potrzeby. W drugim przykazaniu napisano: "Nie będziesz wzywał imienia Pana, Boga twego, do czczych rzeczy, gdyż Pan nie pozostawi bezkarnie 
tego, który wzywa Jego imienia do czczych rzeczy" (Biblia Tysiąclecia, Wj 20:7). W Chinach zakazane było wymienianie imienia cesarza a nawet własnych przodków - tzw. tabu imion (避讳, bì hui). Nadal uważa się za niegrzeczne nazywanie swoich rodziców, dziadków itd. po imieniu, a za przynoszące nieszczęście dawanie dziecku imienia po przodkach.

Najsłynniejszym tabu imion jest zapewne tabu imienia pierwszego cesarza, którego nazwisko rodowe brzmiało Yíng (嬴), a imię Zhèng (政). Ponieważ 政 brzmiało identycznie jak występujące w nazwie pierwszego miesiąca roku 政月 ('miesiąc administracyjny'), należało je zastąpić znakiem 正 ('główny') wraz ze zmianą tonu z zhèng na zhēng, a wreszcie, by uniknąć wszelkiego podobieństwa w wymowie, znakiem 端 $d u \bar{a} n$ ('właściwy').

\section{Miejsce zwierząt w kulturze chińskiej}

Wczesny system wierzeń na terenie obecnego państwa chińskiego opierał się na totemizmie oraz animizmie. Totemizm oznaczał wiarę $\mathrm{w}$ pochodzenie danej grupy od wspólnego przodka przedstawionego jako roślina, zwierzę lub istota fantastyczna, półboska. Mniejszość Yao wierzy na przykład, że pochodzi od psa (Eberhard 2007: pies), ludy z czasów dynastii Yin wywodziły natomiast swoje korzenie od psa, barana czy niedźwiedzia (Wasiliew 1975: 51). Wiara ta przekładała się na tabuizowanie tychże totemów i pewnych czynności z nimi związanych (ludność Yao nie spożywa psiego mięsa, ani nie zabija psów). Podobnie władcy wywodzili swój ród od fantastycznych przodków. Wasiliew (1975: 51 n.) stwierdza, że takie boskie pochodzenie było w pewnym sensie obowiązkowe:

[K]iedy Liu Pang, chłop z pochodzenia został cesarzem, założycielem dynastii Han, musiał wymyślić sobie jakiś totem. Jego przodkiem-totemem ogłoszono oficjalnie smoka, przy czym stworzono wersję o cudownym poczęciu cesarza za sprawą smoka [...].

Smok w późniejszym czasie stał się zwierzęciem przypisywanym na stałe cesarzowi.

Oprócz wierzeń totemistycznych ważną rolę w okresie przejścia od zbieractwa do rolnictwa odgrywał także wspomniany animizm, ożywiający potężne siły natury i przypisujący zwierzętom czy roślinom boskie moce. Duchy wód, gór czy lasów przedstawiano nierzadko jako zwierzęta, przy czym konkretne gatunki przypisywano konkretnym miejscom. Smoka łączono zwykle z wodą, tygrysa z górami, kruk symbolizował słońce, a zając księżyc. Wraz z animizmem rozwijał się kult płodności oraz pierwiastków męskiego i żeńskiego, przedstawianych w postaci dopełniających się pól koła: ๑.

Duchy i totemy miały ogromny związek $\mathrm{z}$ powszechnym nawet $\mathrm{w}$ dzisiejszych Chinach kultem przodków. Totem czczono jako wielkiego przodka-założyciela, co z kolei dało początek wspomnianemu tabu imion, 
jako że Chińczycy często przyjmowali imię swojego totemu. Każda rodzina miała swoją kapliczkę lub ołtarzyk z wyobrażeniem przodka, któremu składano w ofierze pokarm lub palono kadzidło. Kult przodków rozpoczął się już w czasach dynastii Shang (XVII - XI w. p.n.e.), jednakże największą popularność osiągnął wraz z myślą Konfucjusza (Olszewski 2003: 86, 90), który określał rodzinę jako podstawę społeczeństwa, a opieka nad starszymi należała do cnót podstawowych.

W okresie panowania dynastii Han konfucjanizm nabrał cech doktryny synkretycznej. Włączono do niego np. elementy dawnych wierzeń czy taoizmu. Elementami dość istotnymi, które w owym czasie weszły do systemu „oficjalnych” wierzeń, była teoria o pierwiastkach żeńskim i męskim, yin i yang oraz teoria pięciu elementów. Yin i yang uosabiały chaos i porządek jednocześnie, idealną równowagę wszechświata, przeciwieństwa, które się wzajemnie dopełniają. Pięć elementów (czy też żywiołów -ziemia, drewno, metal, ogień, woda) symbolizowało odwieczny cykl życia, zniszczenia i odrodzenia. Żywiołom przyporządkowano lata, pory roku, strony świata, zwierzęta (owca, kogut, wół, pies, świnia), kolory, smaki itd. Ten porządek miał swoje odzwierciedlenie w chińskim kalendarzu, rządzącym życiem każdego Chińczyka.

Tradycyjny kalendarz chiński był kalendarzem luni-solarnym, opartym na 6o-letnim cyklu. Wyznaczało go 10 „niebiańskich pni”, oznaczanych pięcioma żywiołami w wariantach yin lub yang oraz 12 „ziemskich gałęzi” (odcinków wędrówki Jowisza) reprezentowanych przez 12 zwierząt zodiakalnych. Ziemskie gałęzie wyznaczały nie tylko lata, ale także miesiące i pory dnia. Zwierzę zodiakalne patronowało osobie urodzonej pod danym znakiem, a nawet determinowało cechy osobowe. Horoskop służył do dobierania par małżeńskich. Jako że kombinacje sprzyjające i niesprzyjające występowały równie często, łatwo można było odmówić małżeństwa, nie uchybiając rodzinie potencjalnego współmałżonka.

Samo pochodzenie chińskiego zodiaku jest niepewne. Niektóre $\mathrm{z}$ chińskich podań utrzymują, że to bogowie oceniali cechy zwierząt i tak przyznawali im kolejność, inne, że 12 zwierząt zodiakalnych było jedynymi żegnającymi Buddę. Pierwszym zwierzęciem miał być silny wół, jednakże szczur, bojąc się o swoje miejsce, wskoczył wołu na grzbiet i zeskoczył dopiero, by zająć pierwszą pozycję (Eberhard 2007: szczur). Kolejność ustaliła się następująco (podkreśleniem oznaczono zwierzęta opisywane w dalszej części artykułu):
1. $\operatorname{szczur}($ 鼠, shŭ)
2. wół (牛, niú)
3. tygrys (虎, hŭ $)$
4. zając (兔, tù)
5. smok (龙, lóng)
6. wąż (蛇, shé)
7. koń (马, mă)
8. owca/koza (羊, yáng) 
9. małpa (猴, hóu)

10. kogut (鸡, $\bar{j}$ )

11. pies (狗, gŏu)

12. świnia (猪, zhū)

Wół jako zwierzę robocze otaczany był wielkim szacunkiem. Niektórzy Chińczycy z tego powodu nie jedli wołowiny, choć mógłby to być także wpływ buddyzmu. Wół symbolizował także prace polowe na wiosnę; łączono go z wodą i płodnością. Tygrysowi, królowi gór i zwierzęciu przerażającemu swoją potęgą składano ofiary błagalne. Strach przed tygrysem był tak wielki, że jego imię obłożono tabu. Mówiono o nim 'czcigodny tygrys' (老虎, lăohŭ) lub też unikano całkowicie wymawiania 虎 i określano go jako 'wielkiego robaka' (大虫, dà chóng) czy 'króla gór' lub też, jak w kalamburze, 'cynobrowego' (丹丹, dāndān; przysłowie 虎视眝眝 hŭ shì dān dān jest homofoniczne z 'tygrys jest cynobrowy', 虎是丹丹). Tygrys był jednakże oceniany pozytywnie, gdyż chronił przed demonami i symbolizował wielką odwagę oraz męską siłę. Pierwiastek męski, zapładniający wiązany był ze smokiem, któremu przypisywano wiele znaczeń symbolicznych. Był opiekunem nieba i cesarza, przedstawicielem zwierząt łuskowych (wg symboliki pięciu elementów), dawcą deszczu. Istniało wiele rodzajów smoków, jednakże największa ilość podań opowiada o smokach wodnych. Siódmym zwierzęciem chińskiego zodiaku był koń. Wedle wielkości dzielono je na 'smocze’ do ośmiu stóp (尺, ok. 23 cm) wysokości (龙马, lóng mă), konie do siedmiu stóp (騋, lái) oraz zwykłe konie do sześciu stóp. Koń to pierwiastek męski w opozycji do krowy, pierwiastka żeńskiego. Często wymieniano go w kontekstach wojennych, ale także gdy chodziło o pracę na roli. Kura czy kogut opisywane były pozytywnie. Odpędzały demony i miały przynosić powodzenie, ponieważ 'koguci grzebień' był homofonem wyrazu 'urzędnik'. Kurze jaja i kości służyły do wróżenia. Do odpędzania duchów służyły także psy. W ich odchodach zanurzano opętanych.

Zwierzęta w kulturze chińskiej pojawiały się w zodiaku oraz, jak wspomniano, w teorii pięciu elementów. Teoria ta uwzględniała nie tylko pięć kategorii zwierząt (łuskowate, owłosione, nagie, skorupiaki, opierzone), ale też pięć zwierząt domowych, czy pięć jadowitych. Każda ze stron świata (wschód, zachód, północ, południe oraz środek) miała odpowiadające sobie zwierzę (biały tygrys, szmaragdowy smok, czarny żółw, czerwony ptak/feniks oraz żółty smok). Charakterystyczne było także przyjmowanie zwierzęcia-totemu dla swojego rodu oraz przyznawanie siłom natury symbolu w postaci zwierzęcia. Co jednak ważne, nie ma jednego systemu, opisującego chińskie wierzenia. Jak napisał Olszewski (2003: 83):

[p]rzedstawienie duchowego dorobku dawnych Chin jest rzeczą niezwykle trudną. Różnorodność kultów i prądów filozoficznych nie pozwala na pełną prezentację zagadnienia, wymieszanie zaś rozmaitych elementów i ich 
równolegle funkcjonowanie $\mathrm{w}$ swoistej symbiozie czy nawet syntezie stanowi ewenement na skalę światową.

Dlatego też wartości i cechy przypisywane różnym zwierzętom mogą różnić się znacząco w zależności od epoki, terenu czy wyznawanych wierzeń.

\section{Wartości we frazeologii}

\subsection{Pies (狗)}

Eberhard (2007: pies) pisze: „Choć pies jest jedenastym zwierzęciem chińskiego zodiaku, zwykłego psa nie traktuje się w Chinach szczególnie dobrze" Takie samo stwierdzenie można by odnieść do związków wyrazowych zawierających znak 狗, które zwykle opisują negatywne cechy ludzkie. I tak oto zachowanie zuchwałe i bezczelne może zostać podsumowane stwierdzeniem 'odwaga psa jest większa od nieba' (狗胆包天 gŏu dăn bāo tiān, tj. niesamowicie zuchwały). Psa wiąże się również z zawziętą walką o własną pozycję (狗咬狗 gŏu yăo gŏu, 'pies gryzie psa', tj. walka w obrębie kliki; zacięta walka równych sobie), wykorzystywaniem cudzej pozycji i władzy (狗丈人势 gŏu zhàng rén shì, 'pies groźny dla ludzi, kiedy ma za sobą swojego pana', tj. tyranizować i zastraszać, mając wsparcie potężniejszej od siebie osoby, „mieć plecy”) dla zapewnienia sobie korzyści (狗苟蝇营 gŏu gŏu yíng yíng, "pies szuka schronienia, mucha leci do świni’, tj. dbać o swój własny interes; podążać za sławą i fortuną niezależnie od kosztów), a nawet z lizusostwem i służalczością (狗颠屁股 gŏu diān pìgu 'pies macha tyłem', tj. podlizywać się; 狗腿子 gŏu tǔ̆zi, 'psia noga', tj. pachołek, sługus, wspólnik).

Jednocześnie pies to symbol osoby o niskiej pozycji, która się wywyższa (狗眼看人低 gŏu yăn kàn rén dī, 'pies patrzy na człowieka z góry', tj. być snobem, wywyższać się) i wtrąca w cudze sprawy (狗拿耗子 gŏu ná hàozi, 'pies łapie myszy', tj. wtykać nos w nieswoje sprawy), często nieumiejętnie (狗 \囚 gŏu tóu jūnshī, 'psiogłowy doradca wojenny', tj. nieudolny, zły doradca), dobre rady odbierając jako atak na siebie (狗咬囚洞囚 gŏu yăo Lü Dòng Bīn, 'pies gryzie Lü Dòng Bīna (jednego z ośmiu nieśmiertelnych)', tj. źle odebrać dobre zamiary; wziąć kogoś dobrego za złoczyńcę).

Psia skóra to oszukańczy lek, którym reklamują się fałszywi znachorzy (狗皮膏药 gŏupígāoyao, 'okład z psiej skóry', tj. pierw. okłady w chińskiej medycynie; ob. oszukańczy lek, produkt; 卖狗皮亭药 mài gŏupí gāoyao, 'sprzedawać okład z psiej skóry', tj. robić sobie fałszywą reklamę).

Psia krew używana była w taoistycznych rytuałach do wykrywania demonów lub obrony przed nimi. Lżenie i obrzucanie wyzwiskami przyrównuje się do psiej krwi tryskającej na czyjąś twarz w trakcie takiego 
rytuału (狗血喷头 gŏuxuè pēn tóu, 'psia krew tryska na głowę', tj. strumień inwektyw).

'Psie gazy' (狗屁 gŏupi) funkcjonują zupełnie jak ang. bullshit lub horseshit, oznaczając bzdury, głupoty lub kłamstwa. Osoby i przedmioty bezwartościowe określa się jako gorsze od psich gazów (狗屁不如 gŏupì bù rú, 'niewart psich bąków', tj. nic niewart), niedorównujące im.

O niskiej wartości psa świadczy przysłowie 狗尾续貂 $g$ ŏu wěi xù diāo ('doczepiać psi ogon do soboli', tj. pierw. ironicznie o pośpiesznym nadawaniu zaszczytów; ob. niepotrzebna kontynuacja dobrego dzieła), gdzie psi ogon psuje efekt całości.

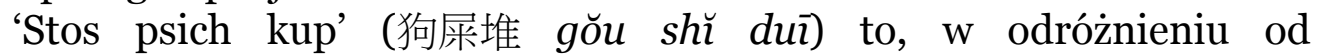
wspomnianego bullshit, człowiek odrażający i znienawidzony. Pies symbolizuje brak manier oraz obrzydliwe (狗㪍不如 gŏu zhì bùrú, 'gorszy od psa i świni’, tj. podły, ohydny) i wulgarne (狗嘴里吐不出象牙 gŏu zuй lı̆ tŭ bù chū xiàngyá, 'z pyska psa nie wyjdzie kość słoniowa', tj. wulgarni ludzie będą tylko klaćc; świnia zostaje świnią choćby na sobie złote siodło miała) zachowanie, którego nie da się w żaden sposób zmienić (狗改不了吃屎 gŏu găi bùliăo chī shŭ, 'pies nie zmieni nawyku jedzenia odchodów’ lub 狗要吃屎, 沙糖换弗转 gŏu yào chī shŭ, shā táng huàn fú zhuăn, 'jeśli pies chce jeść ekskrementy, cukier mu tego nie zastąpi', tj. złych ludzi nic nie powstrzyma od bycia złymi).

Wiele z tych określeń odnosi się do naturalnych zachowań psów (np. gryzienie bez powodu i obszczekiwanie). Odpowiednikiem polskiego tonacy brzytwy się chwyta będzie także przysłowie sięgające do obserwacji natury (狗急跳墙 $g$ ŏu jí tiào qiáng, 'pies w desperacji skacze na ścianę' lub 狗急跳墙, 人急县梁 gŏu jí tiào qiáng, rén jí xuán liáng, 'pies w desperacji skacze na ścianę, człowiek w desperacji się wiesza', tj. tonący brzytwy się chwyta).

\subsection{Tygrys (虎)}

Tygrys w Chinach jest symbolem męskości (虎贲 hŭ bēn, 'tygrysi bieg', tj. przest. wojownik 'jak tygrys ścigający zwierzynę’) jako zwierzę przypisywane żywiołowi yang (Eberhard 2007: tygrys). Jako pan zachodu, jesieni i śmierci (biały tygrys; pogardliwe określenie kobiety związane $\mathrm{z}$ żywiołem yin) występuje często razem ze swoim przeciwieństwem, smokiem (zielono-niebieski smok), panem wschodu i płodności. Jest trzecim zwierzęciem zodiakalnym. Oznacza wielką siłę i odwagę (虎将 hŭ jiàng, dzielny dowódca', tj. odważny, silny dowódca), żywiołowość i żywotność (虎劲 hŭ jìn, 'tygrysia siła', tj. nieposkromiona żywiołowość, śmiałość; 虎虎有生气 hŭ hŭ yŏu shēngqi, 'energia tygrysa', tj. pełen życia, energetyczny - znak 虎 jest także przymiotnikiem ‘żywotny’) oraz zdrowie (虎背熊腰 hŭ bèi xióng yāo, 'plecy tygrysa, talia niedźwiedzia', tj. krępy, mocno zbudowany, duży i silny; 虎头虎脑 hŭ tóu hŭ năo, 'tygrysia głowa, tygrysi mózg', tj. zdrowo wyglądać - o chłopcach). Tygrys to także symbol 
wielkości i potęgi (虎父无犬子 hŭ fù wú quăn ž̆, 'z ojca tygrysa nie będzie psów', tj. wielkość ojca przechodzi na syna; a nawet 虎头蛇尾 hŭ tóu shé wěi, 'tygrysia głowa, ogon węża', tj. zacząć z zadęciem i skończyć bez rezultatu).

Tygrys pojawia się często jako symbol niebezpieczeństwa (虎踞龙盘 $h \breve{u}$ jù lóng pán, „przyczajony tygrys, ukryty smok” - strategicznie niebezpieczne i ważne miejsce lub teren niebezpieczny, pozwijany jak smok; często mianem tym określany jest teren Nankinu, gdzie smokiem jest na wschodzie Zhongshan, a tygrysem na zachodzie Kamienne Miasto; 虎口 hŭkŏu, 'paszcza tygrysa', tj. śmiertelne niebezpieczeństwo; 虎口拢牙 hŭkŏu báyá, 'wyrwać ząb ze szczęki tygrysa', tj. odważyć się na największe niebezpieczeństwo; 虎视眝眝 hŭ shì dān dān, 'intensywnie patrzeć jak tygrys', tj. wgapiać się ‘jak tygrys patrzący na swoją ofiarę’; 虎俔出柙 hŭ sì chū xiá, 'tygrys, nosorożec wyskakują z klatki', tj. winny poważnego zaniedbania); jest zwierzęciem groźnym i walecznym, i dlatego też uosabia ryzyko (虎穴追踪 hŭxué zhuīzōng, 'tropić tygrysa do jego legowiska', tj. podążać za wrogiem do jego kryjówki; 虎尾春冰 hŭ wěi chūn bìng, dosł. 'ogon tygrysa, lód na wiosnę', 'deptać po ogonie tygrysa, chodzić po lodzie wiosną, tj. być na niepewnej pozycji). Często pojawia się w żargonie wojskowym (虎贲 hŭ bēn, 虎将 hŭ jiàng, 虎踞龙盘 hŭ jù lóng pán, 虎穴追踪 hŭxué zhuīzōng).

\subsection{Kogut/kura (鸡)}

Dziesiątym znakiem chińskiego zodiaku jest kogut 公鸡. Sam znak 鸡 jest niejednoznaczny, jako że jest nazwą rodzajową oznaczającą kurę (Gallus gallus domesticus) a jednocześnie kokoszę.

Mimo pozytywnej męskiej symboliki przypisywanej kogutowi zodiakalnemu, przysłowia odnoszące się do kury jako takiej niosą ze sobą ładunek negatywny. Kurę rozpatruje się raczej jako pospolite zwierzę domowe, niż symbol zodiakalny czy mistyczny. Znak 鸡 jest składnikiem związków wyrazowych określających rzeczy małe, nieistotne, ułamkowe, bezsensowne (鸡毛赫皮 jī máo suàn pí, 'kurze pióro, łupina czosnku', tj. bzdury, drobiazgi; 鸡零狗碎 ji líng gŏu sui, 'kurzy fragment, psi fragment', tj. fragmentaryczny, niecałkowity; bzdury, drobiazgi; 鸡肋 jì lèi, 'kurze żeberka', tj. rzeczy o niewielkiej wartości, drobiazgi, nic istotnego; 鸡虫得失 jī chóng dé shī, 'kura nie może złapać robaka', tj. niewielkie, nieistotne straty).

Kura symbolizuje także osoby o niskim pochodzeniu, niewiele znaczące w hierarchii, które jednak mogą osiągnąc zaszczyty, czy to poprzez zaciętą walkę i układy (鸡丞争食 jī wù zhèng shí, 'kury i kaczki walczące o jedzenie', tj. ludzie bez znaczenia walczący o władzę; 鸡犬升天 $j i$ quăn shēng tiān, 'kury i psy wstępują do nieba', tj. promować swoich znajomych i podwładnych; nepotyzm, „kolesiostwo”; 鸡伏鹄卵jī fú hú luăn, 'kura wysiaduje łabędzie jajo', tj. zajmować wysoką pozycję niewiele 
umiejąc) czy też dzięki własnej ciężkiej pracy (鸡窝里飞出金凤囯 $j \bar{\imath} w \bar{~} l \breve{l} f e ̄ i$ chū jīn fènghuáng, 'z kurzego gniazda wylatuje złoty feniks', tj. osoba o skromnym pochodzeniu dochodzi do zaszczytów). 鸡犬升天 jī quăn shēng tiān występuje także w wersji 淮南鸡犬 Huáinán jī quăn, 'kury i psy Huainanu', tj. przebywać li tylko z osobami mogącymi osiągnąć sukces. Legenda mówi, że kiedy król Huainanu osiągnął oświecenie/nieśmiertelność, kury i psy zjadły płatki poświęconych róż i tym samym również wstąpiły do nieba.

Zwyczajowe chińskie powiedzenie, wskazujące na ścisłą hierarchizację społeczeństwa (鸡毛上不了天 j̄ máo shàng bùliăo tiān, 'kurze pióro nie może sięgnąć nieba', tj. osoba o skromnym pochodzeniu nie dojdzie do zaszczytów), przekształcone zostało przez Mao Zedonga w 1958r. （鸡毛[也能]飞上天 j̄̄ máo [yě néng] fēi shàngtiān, 'kurze pióro też może sięgnąć nieba', tj. osoba o skromnym pochodzeniu może dojść do zaszczytów) właśnie po to, by wskazać, że osoby nisko urodzone wciąż mogą przełamać panujące obyczaje. Kurę przeciwstawia się także potężnemu feniksowi (鸡不及凤 jī bù jí fèng, 'kura nie dorównuje feniksowi', tj. syn nie dorównuje ojcu). Lepiej jednak być zwykłą kurą, niż pchać się do wielkiego świata (鸡口牛后 jī kŏu niú hòu, 'kurzy dziób, krowi zad' lub 宁为鸡 $\square$, 无为牛后 nìng wéi ji kŏu, wú wéi niú hòu, 'woleć być kurzym dziobem, niż tyłkiem krowy', tj. lepiej być samemu sobie panem w małym świecie, niż sługusem w wielkim świecie).

Kurze jajko symbolizuje kruchość i słabość. Rzucanie jajkiem w kamień (鸡蛋碰石头 jūdàn pèng shítóu) to walenie głową w mur, bezsensowna walka przeciw silniejszemu. Rozbite jajka (鸡飞蛋打 jū fēi dàn dă, 'kura odleciała, jajka rozbite') to sromotna klęska, a przebijanie skorupki to szukanie dziury w całym (鸡蛋里挑骨头 j̄idàn lı̆ tiāo gŭtóu, 'szukać kości w jajku'). Kurza skóra oznacza osobę w podeszłym wieku (鸡皮鹤发 jī pí hè fā, 'kurza skóra, żurawie włosy', tj. pomarszczona skóra, białe włosy; oznaki podeszłego wieku; osoba starsza, siwa i pomarszczona).

Kura jest także nieodzownym elementem gospodarstwa. Pianie koguta i szczekanie psów wskazuje na obecność bliskich sąsiadów (鸡犬之声相闻, 老死不相往来 j̄̄ quăn zhī shēng xiāng wén, lăo sŭ bù xiāng wănglái, 'zestarzeć się i umrzeć, nie odwiedzając nikogo, mimo że pianie ich kogutów i szczekanie psów słychać w pobliżu', tj. nie mieć kontaktu z innymi, być samotnikiem). Psy i kury są też najniższym w hierarchii ale potrzebnym elementem codziennego życia. Armia okupanta, która nie wystraszyła kur i psów to armia zdyscyplinowana (鸡犬不惊 $j \bar{\imath}$ quăn bù jīng, 'nawet ptactwo i psy się nie boją'), natomiast prześladowanie i zabijanie kur oraz psów oznacza armię bezwzględną (鸡犬不留 jī quăn bù liú, 'nawet ptactwa i psów się nie pozostawia'). Ogólna panika i zamieszanie wyraża się poprzez niespokojne kury i psy (鸡犬不宁 $j \bar{\imath} q u a ̆ n$ bù níng, 'nawet ptactwa i psów nie pozostawia się w spokoju'). Kurze pióro 
symbolizowało w dawnych czasach pilną wiadomość na polu bitwy (鸡毛信 jī máo xìn, 'list z kurzym piórem').

Kiepski podstęp określany jest jako pianie koguta i psie złodziejstwo (鸡鸣狗盗 jī míng gŏu dào, 'piać jak kogut i kraść jak pies', tj. uciekać się do kiepskich sztuczek, źródło opisane poniżej). Najwięcej zaś negatywnych emocji niesie znak 鸡 w określeniu鸡奸 jī jiān - 'sodomita, zboczeniec'.

Powiedzenie鸡鸣狗盗 jī míng gŏu dào pochodzi z dzieła 《史记》Sh $J i$ 'Zapiski historyka' z II/I w. p.n.e., z biografii lorda 孟尝 Meng Changa. Historia opowiada o podróży lorda Meng Changa do Qin, gdzie został zatrzymany w areszcie domowym. Uwolnić mogła go tylko królewska konkubina, w zamian za co zażyczyła sobie drogiego futra z lisa śnieżnego. Futro to było już niestety $\mathrm{w}$ skarbcu króla, jako prezent. Jeden $\mathrm{z}$ przybocznych lorda przebrał się więc za psa i wykradł futro. Lord Meng Chang został uwolniony. W drodze do domu zatrzymany został na przełęczy Hangu, dopóki nie zapieją pierwsze kury. Inny z przybocznych, wiedząc, że są ścigani, począł udawać koguta, budząc tym inne ptaki, i tak oto przepuszczono całą świtę przez przełęcz.

\subsection{Smok (龙)}

Smok jest piątym znakiem chińskiego zodiaku, symbolem męskości (w kontraście do feniksa) i cesarza. Jest władcą wschodu, deszczu i płodności (Eberhard 2007: smok). Chętnie przedstawiany w chińskiej kaligrafii, dodaje obrazom życia (龙飞凤舞 lóng fēi fèng wŭ, 'latające smoki, tańczące feniksy', tj. żywa, pełna krętych linii kaligrafia; 龙腾虎跃 lóng téng hŭ yuè, 'smok wnosi się, tygrys skacze', tj. scena ożywienia; 龙蛇飞动 lóng shé fēi dòng, 'smok leci, wąż pełźnie', tj. żywa, obrazowa kaligrafia).

Smok występuje często razem $\mathrm{z}$ tygrysem jako swoim przeciwieństwem, panem zachodu i śmierci. W tym kontekście smok to władca mórz a tygrys - gór; są to miejsca, do których należą i w których najlepiej się czują (龙不离海, 虎不离山 lóng bù lí hăi, hŭ bù lí shān, 'smok nie opuści morza, tygrys nie opuści gór', tj. osoby przy władzy nigdy nie zechcą oddać swojej pozycji; 龙归沧海, 虎入深山 lóng guī cānghăi, hŭ rù shēn shān, 'smok powraca w głąb morza, tygrys wstępuje w góry', tj. ludzie dążą do miejsc, w których mogą najwięcej osiągnąć). Ich legowiska są synonimem miejsca zdradliwego i niebezpiecznego (龙潭虎穴 lóng tán hŭxué, 'smoczy staw, tygrysia jaskinia', tj. niebezpieczne miejsce). Tym dwóm zwierzętom przypisywana jest ogromna potęga; ich walka (a więc walka władców) sprowadza cierpienia na zwykłych ludzi (龙斗虎争, 苦了小獐 lóng dòu hŭ zhēng, kŭ le xiăo zhāng, 'gdy smok walczy z tygrysem, mały jeleń cierpi’, tj. gdzie dwóch wielkich walczy, tam mali cierpią; niewinni ludzie cierpią, gdy ich władcy walczą).

Smok to także synonim znawcy, wytrawnego konesera (龙眼识珠, 风眼识宝, 牛眼识青草 lóngyăn shí zhū, fēng yăn shí băo, niú yăn shí qīng căo, 'smocze oko rozpoznaje perły, oko feniksa rozpoznaje skarby, a krowie rozpoznaje trawę'). Smocza wątroba oznacza rzeczy 
trudno dostępne, przysmaki (龙肝凤胆 lóng gān fèng dăn, 'smocza wątroba, pęcherzyk żółciowy feniksa'). Ta wyjątkowość smoka przeniesiona zostaje także na związki określające osoby zdolne i obiecujące (龙驹凤雏 lóng jū fèng chú, 'młode smoka i feniksa', tj. inteligentny i obiecujący młody człowiek; 龙马精神 lóng mă jīng shén, 'duch smoczego konia', tj. duch wspaniałego rumaka; zwykle o osobach starszych, ale wciąż żywotnych; znak 龙 oznacza wspaniałego i potężnego konia). $\mathrm{Z}$ nieznanych autorce bliżej przyczyn, 'smocza godzina' (龙钟 lóngzhōng) określa osobę starą, głównie z wyglądu.

Smok i tygrys obrazują majestat zarówno w ruchu, jak i w odgłosach (龙骧虎步 lóng xiāng hŭ bù, 'smok wznosi się, tygrys kroczy', tj. majestatycznie kroczyć; t. bohaterska postawa; 龙吟虎啸 lóng téng hŭ yuè, 'smok śpiewa, tygrys ryczy', o rezonującym, donośnym dźwięku).

Smok i feniks symbolizują talent (龙蟠凤逸 lóng pán fèng yì, 'smok lata, feniks odlatuje', tj. osoba utalentowana, ale niedoceniona; 龙跃凤鸣 lóng yuè fèng míng, 'smok wnosi się, feniks śpiewa', tj. wybitny talent). Dziewięć smoków to liczba magiczna, spotęgowana męskość. Dziewięciu synów smoka jest obdarzonych dziewięcioma talentami, każdy innym (龙生九子 lóng shēng jiŭ ž̆, 'smok miał dziewięciu synów', tj. rodzeństwo z tych samych rodziców różni się od siebie). Złożenie takich życzeń parze młodej podczas uroczystości zaślubin ma przynieść płodność (Eberhard 2007: smok). Smok znajduje także swoje metaforyczne miejsce w hierarchii społecznej. Smoki to ludzie dobrzy, zwykle też dobrze sytuowani (symbol wyższej warstwy społecznej), węże - źli (龙蛇混杂 lóng shé hùnzá, 'przemieszane smoki i węże', tj. źli i dobrzy ludzie przemieszani razem). Stwierdzenie 龙生龙, 凤生凤 (lóng shēng lóng, fèng shēng fèng, 'ze smoka smok, z feniksa feniks', tj. takie ma się dzieci/takich ma się przyjaciół, jakim się jest; ciągnie swój do swego) oddaje zależności społeczne w Chinach i ścisłe uhierarchizowanie społeczne - przedstawiciele poszczególnych klas znajdować mają sobie przyjaciół i przyszłych małżonków zgodnie ze swoim statusem.

\subsection{Koń (马)}

Koń to siódme zwierzę zodiakalne. Eberhard (2007: koń) podaje, że w Księdze Przemian koń symbolizował pierwiastek żeński, natomiast w późniejszym czasie męski, jako przeciwieństwo żeńskiej krowy. We frazeologii koń jest rzeczywiście rozpatrywany zwykle jako ogier, zwierzę silne i szybkie (马不停蹄 mă bù tíng tí, 'koń nie zatrzymuje kopyt, koń w galopie', tj. bez przerwy, nie zatrzymując się; 马上 măshàng, 'na koń', tj. co koń wyskoczy, natychmiast). Symbolizuje on natychmiastowy sukces (马上 măshàng, w kaligrafii małpa na koniu oznacza życzenie "obyś natychmiast osiągnął urząd”; 马到成功 $m a ̆$ dào chéng gōng, “zwyciężyć wraz z przybyciem koni’). Często występuje w kontekście militarnym, jako zwierzę bojowe (马到成功 mă dào chéng gōng; 马仰人翻 mă yăng rén fān, 'konie i 
ludzie poprzewracani, zbici z nóg', tj. boleśnie pobity, pokonany; t. gorączkowy i chaotyczny). Na polu bitwy zmarłych zawija się w końską skórę przy braku całunu (马革裹尸 mă gé guŏ shī , 'ciało zawinięte w końską skórę', tj. zginąć na polu bitwy). Koń bojowy figuruje także na chińskiej szachownicy. Ustawienie konia za armatą symbolizuje przegapienie właściwego ruchu i spóźnioną reakcję czy też radę (马后炮 mă hòu pào, 'czarny koń za czerwoną armatą'). Podążanie za głową konia to bezwarunkowe podążanie za kimś (kierowanie się za koniem, na którym siedzi dowódca), obranie go za wzór (马首是瞻 mă shŏu shì chān, 'spoglądać na głowę konia').

Koń i tygrys to wedle historii pochodzącej $\mathrm{z}$ dzieła 《聊斋志异》 Liáozhāi zhìyi 'Osobliwe historie z Liaozhai' (XVII/XVIII w.) niedbała robota. Autor opisuje, jak nadworny malarz dynastii Song malował zwierzę, po czym raz odpowiadał, że to tygrys, innym razem, że to koń. Syn malarza, zobaczywszy na polowaniu tygrysa, uznal zgodnie ze słowami ojca, że jest to koń, i postanowił go dosiąść. Niestety, został zjedzony. Do dziś 马虎 i 马马虎虎 (măhu, mămahŭhu, 'koń, tygrys') oznaczają bylejakość i kompletny brak powagi.

Przewrócenie się po chińsku kojarzy się z upadkiem konia (马䟜 mă $p \bar{a}$, 'koń leży', tj. upaść, wywalić się).

Końska stopa ((露)马脚 (lòu) mă jiăo, '(ujawnić) końskie kopyto', tj. zdradzić się, wydać się) to stopa niebandażowana, brzydka, zdradzająca stan (rzekomo przysłowie to opisuje cesarzową Ma, żonę Hongwu $\mathrm{z}$ dynastii Ming (XIV w.), która nigdy nie miała krępowanych stóp, co zdradzało jej niskie pochodzenie). Końskie zęby (马齿徒增 mă chŭ tú zēng, 'końskie zęby wciąż rosną', tj. zmarnować czas, zestarzeć się i nic nie osiągnąć) zdradzają z kolei wiek - i, w tym wypadku, brak jakichkolwiek osiągnięć. Koń jako zwierzę domowe, pociągowe niesie ze sobą także więcej negatywnych znaczeń. Symbolizuje on nieokrzesanie i brak wychowania (马牛襟裾 mă niú jīn jū , 'koń i krowa zakładają ludzkie ubrania', tj. pierw. osoba nieznająca etykiety; t. potwór w ludzkiej skórze, bestia, brutal), a także lizusostwo (马屁精 mă pi jīng, 'esencja końskich gazów', tj. lizus, pochlebca).

Znak 马 może występować także jako nazwisko (马工枚速 mă gōng méi sù, 'Mă pracuje dokładnie, Méi pracuje szybko', tj. ob. każdy ma swoje zalety, mocne strony). W przypadku nazwy na 'nocnik' (马桶 mătŏng, 'końskie wiadro'), która zawiera w istocie nazwisko a nie wyraz 'koń', dochodzi tu także element tabu. Eberhard (2007: tygrys) pisze, że nocnik nosi nazwę 虎子 hŭzi 'tygrys' poprzez podobieństwo do rozwartej szeroko tygrysiej paszczy. Notuje także nazwę 马桶 mătŏng, zaznaczając, że na ślubach ma ono symbolizować płodność i dzieci. Przejście z tygrysa do konia odbyło się na podstawie tabu imion. Cesarz dynastii Tang Taizong chcąc uniknąć profanacji imienia swojego dziadka Li Hu (VI w.), nakazał zmianę nazwy na 马子 măzi 'koń'. 


\subsection{Krowa/bawół (牛)}

Język chiński nie odróżnia krowy, byka, wołu i bawołu. Przyjmuje się, że drugim zwierzęciem chińskiego zodiaku jest wół, jako zwierzę rolne, związane $\mathrm{z}$ wiosną i płodnością. W wielu podaniach ludowych akcentuje się wielką siłę wołu (牛劲 niú jìn, 'krowia siła', tj. wielka siła lub wysiłek). Krowa symbolizuje upartość i przekorność (牛脾气 niú pí qì, 'napowietrzona krowia śledziona', tj. uparty; 牵牛要牵牛鼻子 qiān niú yào qiān niú bízi, 'żeby krowę prowadzić, trzeba wziąć ją za kółko u nosa', tj. do spraw trzeba się odpowiednio zabrać; 牛不喝水强按头 niú bù hē shul̆ qiăng àn tóu, 'zmuszać krowę, żeby piła, wpychając jej głowę do wody', tj. wymuszać na kimś swoją wolę), zaś nadmuchiwanie krowiej skóry to przechwalanie się (吹牛皮 chuĩ niú pí). Krowę łączy się też ze zmyślaniem (牛无力拉横耙, 人无理说横话 niú wú lì lā héng bà, rén wú lǔ shuō hèng huà, 'krowa nie ma siły ciągnąć brony i zbacza, człowiek niemający nic do powiedzenia kręci i kłamie', tj. nie mieć nic do powiedzenia i zmyślać; 牛皮不是吹的, 火车不是推的 niú pí búshì chuī de, huŏchē búshì tuī de, 'krowia skóra nie jest dmuchana, pociągu się nie pcha', tj. zamiast zmyślać, pokaż, co potrafisz - część druga przysłowia może występować w kilkunastu różnych wariantach, przy czym pojawiają się coraz to nowsze wersje, często zabawne i utworzone pod wpływem zjawisk kulturowych obecnie popularnych.).

Krowa może być także symbolem złego człowieka. W przypadku (牛骥同㿝 niú jì tóng zào, 'krowa i wspaniały rumak mają jednakowy obrok', tj. źli i dobrzy ludzie żyją obok siebie) jest po prostu skontrastowana z koniem, natomiast przykłady (牛鬼蛇神 niú guı̆ shé shén, 'duchy wołów i węży', tj. demony, źli ludzie wszelkiego rodzaju; 牛头马面 niú tóu mă miàn, 'krowia głowa, koński pysk', tj. pierw. potwory w buddyjskim piekle, ob. przeraźliwie brzydcy ludzie) sięgają do chińskiej demonologii. 'Krowiogłowi' to ludzie piekielnie brzydcy (牛头马面 niú tóu mă miàn) lub też rzeczy bezsensowne i niespójne (牛头不对马嘴 niú tóu búduì mă zŭ, 'końskie szczęki nie pasują do krowiej głowy', tj. niespójny, nierelewantny, „kupy się nie trzyma”).

Krowa, co wydaje się być zaskakujące, łączona jest także z rzeczami drobnymi. 'Koniuszek krowiego rogu' (牛角尖 niú jiăo jiān) oznacza mało istotny problem, w przeciwieństwie do np. polskiego zapędzić w kozi róg. Jednakże (钻牛角尖 zuàn niú jiăo jiān, 'zagłębiać się w/badać koniuszek krowiego rogu', tj. niepotrzebnie zajmować się nieistotnym lub nierozwiązywalnym problemem lub być w ślepym zaułku) będzie już miało znaczenie zbliżone. Krowia sierść symbolizuje drobny deszcz, kapuśniaczek, mżawkę (牛毛细雨 niú máo xì yŭ, 'jedwabny deszcz jak krowia sierść'). 'Krowie siki' to nazwa babki (Plantago asiatica, arnoglossa), która wraz z purchawką (Lycoperdon z pieczarkowatych) jest elementem chińskiej medycyny - rzeczą powszechnie dostępną, ale nie do 
przecenienia (牛溲马勃 niú sōu mă bó, 'babki i purchawki', tj. niedrogie a przydatne rzeczy).

Wół jest także zwierzęciem rytualnym, składanym w ofierze. 'Gotowanie kury na krowim trójnogu' (牛鼎烹鸡 niú dĭng pēng jī) oznacza marnowanie talentu, a z kolei rytualny nóż (牛刀小试 niú dāo xiăo shì, 'małe nacięcie nożem rzeźniczym', tj. drobna próbka talentu wielkiego artysty) jest symbolem wielkiego talentu.

Biednych ludzi określa się jako tych, którzy żyją wraz ze swoim bydłem (牛衣对泣 niú yī duì qì, 'para płacze w krowim ubraniu', tj. bardzo biednie żyjące małżeństwo). Historia ta ma swój początek w biografii 王章 Wang Zhanga zawartej w dziele 《汉书》Hàn Shū 'Księga Hanów', ukończonym w II w.

\section{Podsumowanie}

W niniejszej pracy założono, że język zawsze wyrastał z kultury i był od niej zależny. Jednocześnie utrwalone połączenia wyrazowe wpływały na kolejne pokolenia, które przejmowały sposób patrzenia na świat swoich przodków. W taki oto sposób tworzy się językowy obraz świata, który opisuje, kategoryzuje i wyjaśnia świat. Ta klasyfikacja zawiera widoczne oraz ukryte wartościowania, które ustalają społeczne reguły i normy. Rekonstrukcja skali wartości może odbywać się na podstawie analizy frazeologii danego języka, która skostniała $\mathrm{w}$ postaci stereotypów określających to, co akceptowalne i to, co jest tabu. Wyrazy typu noa (zastępniki, eufemizmy) pokazują, jak człowiek dostosowywał się do norm za pomocą języka. Jeśli np. w Chinach kulturowo bano się tygrysa, należało unikać wyrazu 'tygrys', zastępując go wyrazem noa lub dodając znak wyrażający szacunek. Jeśli natomiast wyraz 'tygrys' był zakazany przez wzgląd na tabu imion, zmiana następowała ze względów polityczno-społecznych, nie do końca zaś mitologicznych.

Jak już wspomniano, system chińskich wierzeń jest niezwykle rozbudowany. O ile samo opisanie go wydaje się być wyjątkowo skomplikowane, o tyle porównanie wierzeń z systemem języka nastręcza dodatkowych trudności. Nie tylko należy oddzielić połączenia wyrazowe o statusie mitologicznym od tych wynikających $\mathrm{z}$ obserwacji życia codziennego, ale też zwrócić uwagę pochodzenie niektórych z nich z podań po części historycznych, a po części zmyślonych. Kolejnym aspektem jest spora ilość homonimów i polisemów w chińskim oraz izolująca budowa języka, co powoduje, że przysłowia zawierające dany znak niekoniecznie opisują zwierzę - czasem jest to nazwisko (jak w przypadku konia czy tygrysa), czasem zaś roślina (krowa) albo zupełnie inne zwierzę (smok koń).

Wartości i cechy, które przypisywano zwierzętom zodiakalnym stanowiły ważną część codziennego życia ludzkiego. Wpływały one zarówno na kontrolę urodzenia (małżeństwa nierzadko nie życzyły sobie dziecka urodzonego pod niefortunnym znakiem), jak i na zawieranie 
małżeństw, czy podejmowanie innych, także drobniejszych życiowych decyzji.

Znaki zodiaku $\mathrm{w}$ wierzeniach chińskich niosą pozytywny ladunek symboliczny. Zwykle kojarzone są $\mathrm{z}$ płodnością i siłą, sprytem i bogactwem. Jednakże analizując utarte połączenia wyrazowe zawierające nazwy zwierząt zodiakalnych, można dojść do zupełnie innych wniosków. Co prawda smok, zwierzę mityczne, nadal obdarzony jest potęgą i gracją; tak samo tygrys, zwierzę przez Chińczyków szanowane przez pryzmat strachu, opisywany jest jako silny i groźny; ale z kolei zwierzęta domowe, na co dzień przez Chińczyków traktowane nierzadko $\mathrm{z}$ pogardą a przynajmniej uznawane za zwyczajny element życia, w języku określane są jako niezbyt istotne i uosabiają negatywne cechy ludzkie.

Pies w języku chińskim jest symbolem osoby o niskim statusie społecznym, podłej i bezczelnej. Wiązany jest $\mathrm{z}$ małostkowością $\mathrm{i}$ oszustwami. Często pojawia się w towarzystwie kury jako symbol osób nic nieznaczących, pogardzanych. Oba te zwierzęta stoją nisko w hierarchii, a ich awans społeczny oceniany jest negatywnie i kojarzony z układami.

Do zwierząt domowych należą również krowa/wół. Mogą one być postrzegane jako uparte i bezmyślne a nawet złe. Krowa pojawia się także w kontekście wielkiego talentu, gdzie symbolizuje rzeczy wielkie. Oceniana jest raczej neutralnie.

Koń stoi na pograniczu zwierząt domowych (jako koń pociągowy) i bojowych. Związanych jest z nim wiele legend, które na stałe weszły do języka w postaci przysłów. Jako „smoczy koń” symbolizuje szybkość, siłę i natychmiastowy sukces. Występuje w kontekstach wojskowy tak samo jak tygrys i smok, obdarzone wielką mocą i niezwykle groźne. Ich legowiska określają miejsca niebezpieczne i strategicznie położone. Co ciekawe, przypisuje im się także niezwykłą grację i piękno i jako takie chętnie przedstawia w kaligrafii. Zarówno smok, jaki i tygrys uosabiają wysoką klasę społeczną, przy czym smok jest symbolem cesarza, a tygrys totemem wielkich rodów.

Analizując materiał słownikowy stwierdzić można, że zwierzęta w języku chińskim mają przypisaną symbolikę różnego typu, nie zawsze wynikającą $\mathrm{z}$ ich miejsca $\mathrm{w}$ mitologii. Co zaś jest wyraźnie widoczne, to fakt, że ich hierarchia odzwierciedla hierarchię w społeczeństwie chińskim, a frazeologia ich dotycząca niesie ze sobą wiele niewypowiedzianych reguł dotyczących zachowań pożądanych i niepożądanych. Frazeologia ta jest także niezwykle interesująca, ponieważ łatwo można wykazać jej źródła i stwierdzić z całą pewnością, iż przechowuje ona setki, jeśli nie tysiące lat chińskiej kultury i historii. 


\section{Bibliografia}

Allwood, J. 1983. Kan man tänka oberoende av språk? w: U. Teleman (red.) Tal och Tanke. Lund: Liber.

Andersson, L. G. 1985. Fult språk: svordomar, dialekter och annat ont. Stockholm: Carlsson.

Bartmiński, J. 2006. Językowe podstawy obrazu świata. Lublin: Wydawnictwo Uniwersytetu Marii Curie-Skłodowskiej.

Eberhard, W. 2001. Symbole chińskie: słownik: obrazkowy język Chińczyków. Kraków: Towarzystwo Autorów i Wydawców Prac Naukowych Universitas.

Freud, S. 1993. Totem i tabu. Warszawa: KR.

Humboldt, W. 1989. O istocie języka. w: Andrzejewski, B. Wilhelm von Humboldt. Warszawa: Wiedza Powszechna.

Künstler, M. J. 1970. Pismo chińskie. Warszawa: PWN.

Künstler, M. J. 1994. Dzieje kultury chińskiej. Wrocław: Zakład Narodowy im. Ossolińskich.

Künstler, M. J. 2000. Języki chińskie. Warszawa: Wydawnictwo Akademickie DIALOG.

Olszewski, W. 2003. Chiny: zarys kultury. Poznań: Wydawnictwo Naukowe Uniwersytetu im. Adama Mickiewicza.

Wasiliew, L. 1974. Kulty, religie i tradycje Chin. Warszawa: Państwowy Instytut Wydawniczy. 